\title{
BENFONTEIN-02 KIMBERLITE, FREE STATE PROVINCE, SOUTH AFRICA
}

\author{
Mabolani, S1, Cawthorn, R.G2, and Reimold, W.U3. \\ 1De Beers Group Services, Group Exploration, Johannesburg, South Africa \\ 2University of the Witwatersrand, South Africa \\ 3Museum für Naturkunde - Leibniz Institute at Humboldt University of Berlin
}

\section{INTRODUCTION}

Benfontein-02 is a Group I kimberlite sill located approximately $11 \mathrm{~km}$ to the southeast of Kimberley, in the Boshof District, Free State Province. It occurs about 1.5 kilometers to the east of the Benfontein-01 kimberlite, which has been known for its magmatic flow banding and density stratification (Dawson \& Hawthorne, 1973). Following the discovery of the kimberlite in 2004, surface geological mapping was done. Sample analysis for major and trace elements; and mineral identification were done by X-Ray Fluorescence (XRF) and X-Ray Diffraction (XRD) methods using the University of Witwatersrand laboratory facilities.

\section{GEOLOGICAL SETTING}

The three main geological units in the Kimberley area are the Archean Basement Complex, Ventersdorp Supergroup, and the Karoo Supergroup (Clement et al., 1986; Hawthorne, 1968). The Archaean basement is exposed in underground mine workings and comprises banded biotite gneisses that have been dated at 3.2 Ga (Schmitz et al., 2004), as well as amphibolites, chlorite schists and talc schists. Subsequent migmatization and metamorphism have been constrained at 2932 - 2926 Ma (Schmitz et al., 2004). The Ventersdorp Supergroup is represented in the area by the
Platberg Group dated at 2.71 Ga (Armstrong et al., 1991). It rests uncomformably on the Archaean basement and consists mainly of intercalated quartzite, as well as amygdaloidal and massive lavas that are andesitic to basaltic in character (Clement et al., 1986).

The Karoo Supergroup is represented in the area by the Dwyka and Ecca Groups (Hawthorne, 1968). The Dwyka dolerite sills and dykes (Dawson and Hawthorne, 1973). At Benfontein, the kimberlite sills were preferentially emplaced along the contact of dolerite sills with shales. The Benfontein sills areg Crefaceous in age, having

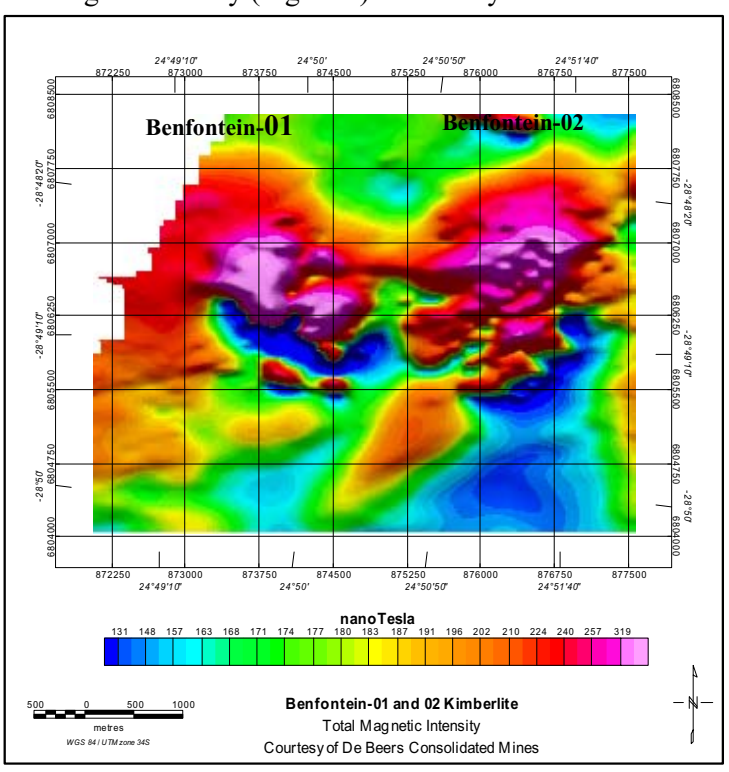

Figure 1: Airborne magnetic map (minimum: 131 nano Tesla and maximum: 319 nano Tesla) depicting the Benfontein-01 and -02 kimberlite sills. 


\section{$10^{\text {th }}$ International Kimberlite Conference, Bangalore - 2012}

been dated at $88 \pm 3 \mathrm{Ma}$ using $\mathrm{U}-\mathrm{Pb}$ perovskite dating (Wu et al., 2010) and intrude the upper shales of the Dwyka Group (Hawthorne, 1968).

\section{MAPPING RESULTS AND GEOPHYSICS OF THE STUDY AREA}

Benfontein-01 and Benfontein-02 sills were detected by an aeromagnetic survey (Figure 1). The study area is characterized by sparse outcrops $(<10 \%)$ of kimberlite, dolerite and shale (Figure 2 ). Kimberlites occur as isolated bodies. The largest kimberlite sill outcrop has a length of 80 $\mathrm{m}$ with varying width. Combined, the sills cover an area of 2.25 ha. Host rock dolerites are hard, greyish-black, medium-grained rocks that are well exposed. Shales are greyish, thinly bedded and mainly weathered.

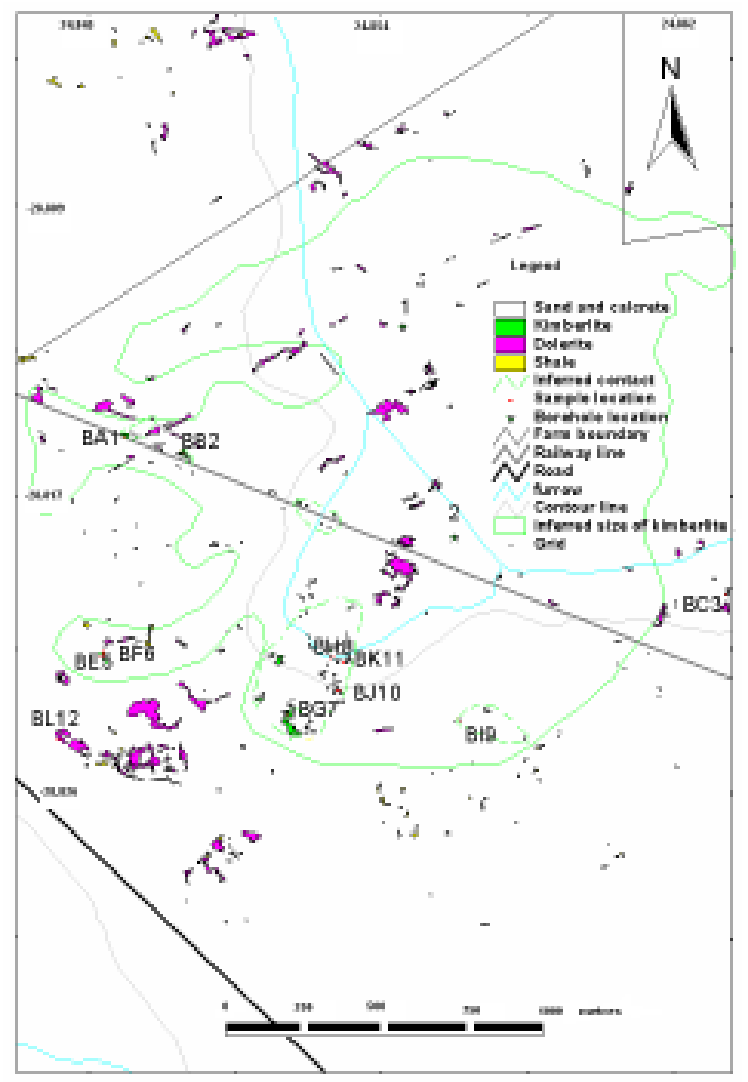

Figure 2: Geological map of the project area (BA1 - BK11 are sample locations; 1 and 2 are borehole locations)
The surrounding host shales have a quiet magnetic background whilst the kimberlite is associated with areas having high magnetic intensities. Two holes drilled into magnetic high features led to the discovery of the kimberlite sills emplaced between dolerite and shale. Dolerite of about $10 \mathrm{~m}$ in thickness forms a cap over the kimberlite. The kimberlite sills have thicknesses varying from 1 to $9 \mathrm{~m}$. As 3a suggested by Mitchell (1986), impermeable layers act as barriers to magma rising during sill emplacement. This mode of occurrence is similar to that of the Benfontein-01 kimberlite.

\section{PETROGRAPHY AND MINERALOGY}

Macroscopically, Benfontein-02 is a dark grey, macrocrystic kimberlite with carbonate veins and patches and minor dolerite xenoliths. Microscopic studies show two generations of olivine (rounded macrocrysts [xenocrysts] and eithedral phenocrysts), spinel, perovskite, apatite, phlogopite and carbonate (Fig. 3a \& b). Serpentinisation is the dominant type of alteration in these rocks, with lizardite being the most prominent alteration product. XRD results indicate the presence of all three serpentine minerals, namely lizardite, chrysotile and antigorite. The

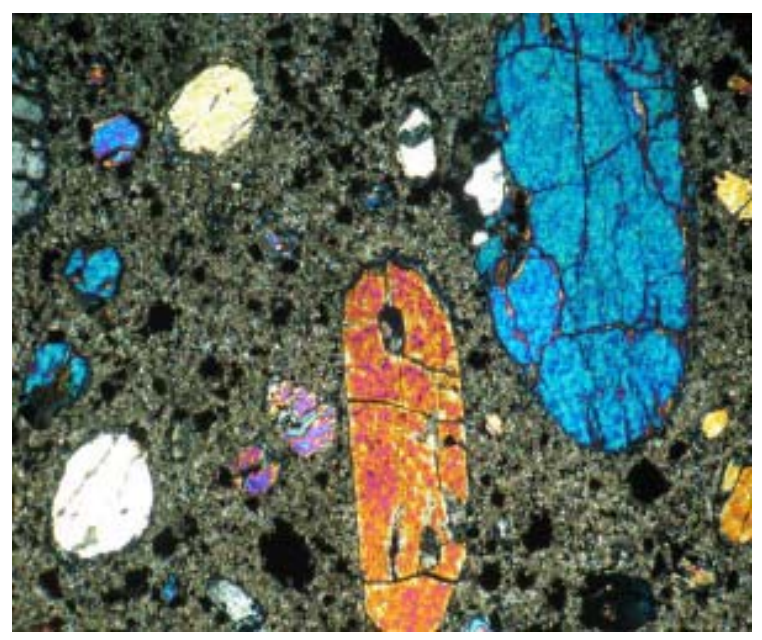

Figure 3a: Photomicrograph displaying ellipsoidal olivine xenocrysts and spinels (sp). 


\section{$10^{\text {th }}$ International Kimberlite Conference, Bangalore - 2012}

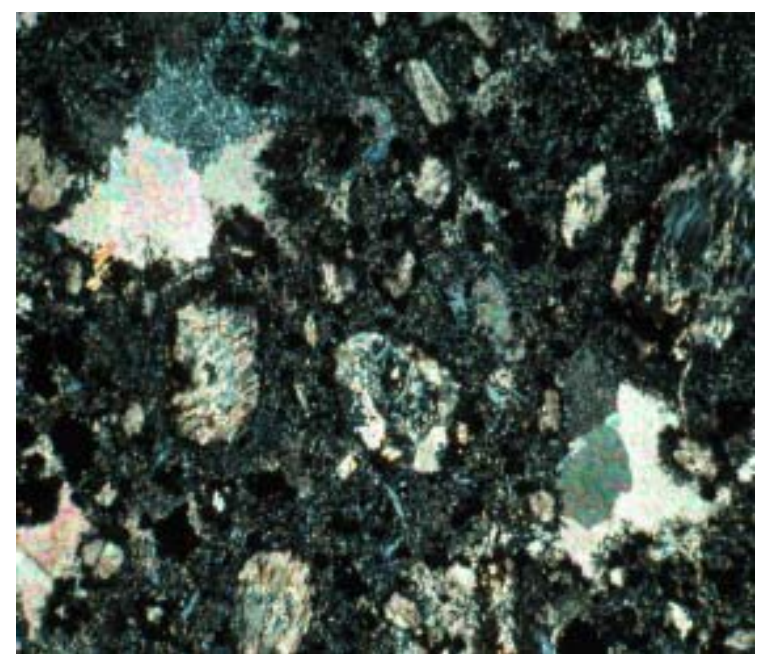

Figure 3b. Photomoicrograph showing carbonate (ca) patches and altered olivines (ol).

kimberlite mineralogy is comparable to that of Benfontein-01 as described by Dawson and Hawthorne (1973).

\section{GEOCHEMISTRY}

Geochemical data of kimberlite samples from Benfontein- 01 and Benfontein-02 are provided in Tables $1 \& 2$.

\section{Major element analyses}

The major element analyses for Benfontein02 are relatively similar to the composite sample of Benfontein-01 kimberlite with slightly higher $\mathrm{LOI}$ and lower $\mathrm{MgO}$ and $\mathrm{K}_{2} \mathrm{O}$, and higher $\mathrm{TiO}_{2}$, contents, which is probably due to a lower abundance of phlogopite and a higher abundance of spinel, respectively. Mitchell (1995) described this relationship as one of the typical characteristics of kimberlites. Like many kimberlites, Benfontein-02 has low $\mathrm{SiO}_{2}$ contents. It has elevated $\mathrm{CaO}$ contents, which is probably due to high carbonate abundance. The Benfontein02 kimberlite has similar $\mathrm{TiO}_{2}, \mathrm{P}_{2} \mathrm{O}_{5}$ and $\mathrm{Al}_{2} \mathrm{O}_{3}$, slightly lower $\mathrm{MgO}, \mathrm{SiO}_{2}, \mathrm{~K}_{2} \mathrm{O}, \mathrm{Na}_{2} \mathrm{O}$ and higher $\mathrm{CaO}$, LOI and FeOT compared to other Group I kimberlites (Dawson and Hawthorne, 1973).
Table 1: Major element analyses of Benfontein02 and a composite Benfontein-01. Sample 1: composite kimberlite; 2: olivine-magnetite- perovskite kimberlite (Dawson and Hawthorne, 1973). Data in wt\%.

\begin{tabular}{|l|l|l|l|l|l|l|}
\hline Kimberlite & \multicolumn{3}{|c|}{ Benfontein-02 } & \multicolumn{2}{c|}{ Benfontein-01 } \\
\hline Sample & BC3 & BF6 & BI9 & BK11 & 1 & 2 \\
\hline $\mathbf{S i O}_{2}$ & 26.68 & 25.17 & 26.14 & 22.18 & 25.19 & 28.63 \\
\hline $\mathbf{T i O}_{2}$ & 1.99 & 2.10 & 2.23 & 2.06 & 1.89 & 1.07 \\
\hline $\mathbf{A l}_{2} \mathbf{O}_{3}$ & 1.98 & 2.08 & 2.07 & 2.33 & 2.87 & 2.01 \\
\hline $\mathbf{F e O}_{\mathbf{T}}$ & 10.40 & 10.60 & 11.30 & 10.30 & 10.40 & 9.40 \\
\hline $\mathbf{M n O}$ & 0.21 & 0.21 & 0.22 & 0.22 & 0.22 & 0.14 \\
\hline $\mathbf{M g O}$ & 28.38 & 25.11 & 28.46 & 24.09 & 29.69 & 34.02 \\
\hline $\mathbf{C a O}$ & 13.59 & 16.62 & 12.55 & 18.17 & 13.59 & 11.92 \\
\hline $\mathbf{N a}_{2} \mathbf{O}$ & 0.00 & 0.00 & 0.35 & 0.00 & 0.01 & 0.20 \\
\hline $\mathbf{K}_{\mathbf{2}} \mathbf{O}$ & 0.03 & 0.06 & 0.10 & 0.10 & 0.15 & 0.05 \\
\hline $\mathbf{P}_{\mathbf{2}} \mathbf{O}_{\mathbf{5}}$ & 1.80 & 2.47 & 1.11 & 2.53 & 2.20 & 0.27 \\
\hline $\mathbf{L O I}$ & 14.63 & 16.09 & 15.76 & 18.10 & 13.98 & 11.74 \\
\hline $\mathbf{H}_{\mathbf{2}} \mathbf{O}-$ & & & & & & 0.23 \\
\hline Total & 99.64 & 100.49 & 100.31 & 100.09 & 100.23 & 99.68 \\
\hline
\end{tabular}

Table 2: Trace element analysis of Benfontein-01 and Benfontein-02 [Benfontein-01 sample: NK, normal kimberlite (Dawson and Hawthorne, 1973)]. Data in ppm.

\begin{tabular}{|c|c|c|c|c|c|}
\hline Kimberlite & \multicolumn{4}{|c|}{ Benfontein-02 } & \multirow{2}{*}{$\begin{array}{l}\text { Benfontein-01 } \\
\mathrm{NK}\end{array}$} \\
\hline Sample & $\mathrm{BC} 3$ & BF6 & BI9 & BK11 & \\
\hline $\mathbf{R b}$ & 10 & 20 & 17 & 9 & 9 \\
\hline $\mathrm{Sr}$ & 1574 & 2084 & 1091 & 1705 & 995 \\
\hline $\mathbf{Y}$ & 25 & 25 & 25 & 23 & 4 \\
\hline $\mathbf{Z r}$ & 311 & 309 & 340 & 307 & 260 \\
\hline Nb & 223 & 240 & 208 & 234 & \\
\hline Co & 67 & 59 & 70 & 60 & \\
\hline $\mathbf{N i}$ & 861 & 715 & 929 & 770 & 1500 \\
\hline $\mathrm{Cu}$ & 65 & 92 & 21 & 83 & \\
\hline $\mathrm{V}$ & 162 & 167 & 103 & 169 & \\
\hline $\mathrm{Cr}$ & 975 & 938 & 1081 & 909 & \\
\hline $\mathbf{B a}$ & 1721 & 1863 & 1146 & 2234 & 1295 \\
\hline $\mathrm{Zn}$ & 91 & 94 & 89 & 84 & \\
\hline
\end{tabular}

\section{Trace element analyses}

The Benfontein-02 kimberlite is classified as belonging to Kimberlite Group I based on the $\mathrm{Nb}$ vs Zr plot (Figure 4) by Taylor et al., (1994). In comparison to the Benfontein-01 kimberlite, the Benfontein-02 kimberlite has higher Rb, Y, $\mathrm{Zr}$, Ba and lower Ni contents. It also exhibits slightly 


\section{$10^{\text {th }}$ International Kimberlite Conference, Bangalore - 2012}

lower $\mathrm{Cr}, \mathrm{Ni}, \mathrm{Rb}$, Co and slightly higher $\mathrm{Ba}, \mathrm{Nb}, \mathrm{Zr}$, $\mathrm{Y}, \mathrm{Zn}, \mathrm{V}, \mathrm{Sr}$ and $\mathrm{Cu}$ contents in comparison to other Group I kimberlites (Dawson and Hawthorne, 1973). Variations in trace element concentrations can be explained by compatibility of $\mathrm{Ni}, \mathrm{Cu}, \mathrm{Co}$ and $\mathrm{Zn}$ in spinel and of $\mathrm{Co}$ and $\mathrm{Ni}$ in olivine as suggested by Smith et al. (1985).

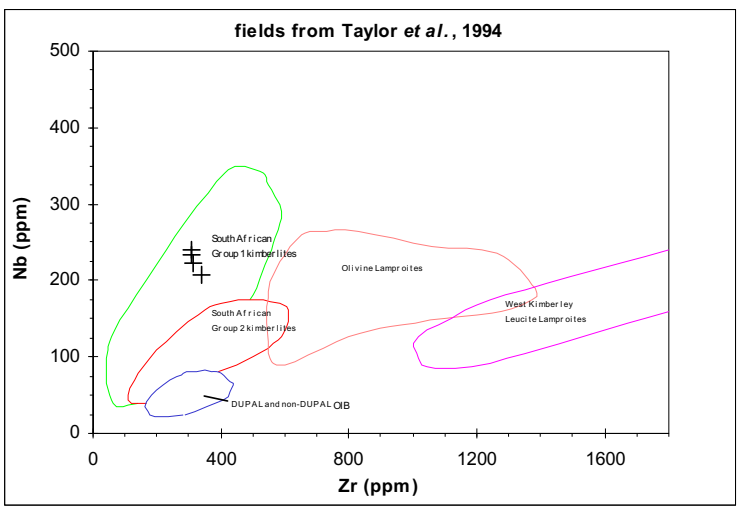

Figure 4: Nb (ppm) vs Zr (ppm) diagram showing the Benfontein02 kimberlite sill samples plotting on the South African Group 1 kimberlites field.

\section{DISCUSSION AND CONCLUSION}

Benfontein-02 kimberlite was detected through aeromagnetic surveying and subsequent drilling. Dolerite forms a cap that acted as a barrier and caused lateral flow and sill development. The Benfontein-02 kimberlite is enriched in carbonate which occurs both as primary and secondary minerals. The former occur as minute patches and their occurrence was described by Hess (1989) as a characteristic feature of co-existence of two liquids. Hess (1989) also indicated that this kind of occurrence is a result of immiscible carbonate and silicate, which separated from the common magma. Similar globular masses were described by Dawson and Hawthorne (1973), who also attributed this to the process of liquid immiscibility. MacMahon and Haggerty (1984) proposed that these features are a result of amygdale infilling, liquid immiscibility, and crystallisation of low temperature residual liquids.
The major similarities between Benfontein01 and Benfontein-02 are that they both contain carbonate patches and few crustal xenoliths (dolerite and shale xenoliths) and are therefore classified as being of the massive hypabyssal type, based on the kimberlite classification by Dawson (1980). What was found different from the Benfontein-01 kimberlite however, is the absence of dendritic calcite, garnets and ilmenite macrocrysts in samples from the study area. In addition to this, phlogopite is rare in the Benfontein-01 kimberlite (Boctor and Boyd, 1981) and occurs as macrocryst (Dawson and Hawthorne, 1973), whereas phlogopite in Benfontein-02 is rare but small in size. Based on these studies, Benfontein-02 is classified as a macrocrystic, carbonate-rich Group I kimberlite.

\section{References}

Armstrong, R.A., Compston, W., Retief, E.A., Williams, I.S., and Welke, H.J. (1991). Zircon ion 4 microprobe studies bearing on the age and condition of the Witwatersrand triad. Precambr. Res., 53, 243-266

Boctor, N.Z. and Boyd, F.R. (1981). Oxide minerals in a layered kimberlite-carbonate sill from Benfontein, South Africa, Contrib. Mineral. Petrol., 76, 253-259.

Clement, C.R., Harris, J.W., Robinson, D.N. and Hawthorne, J.B. (1986). The De Beers kimberlite pipe-A historic South African Diamond Mine. In:Anhaeusser, C.R. and Maske, S. (Eds.), Mineral Deposits of Southern Africa, II. Geol. Soc. S. Afr., 2193-2214.

Dawson, J.B. (1980). Kimberlites and their xenoliths. Springer- Verlag, New York, 522pp.

Dawson, J.B. and Hawthorne, J.B. (1973). Magmatic sedimentation and carbonatitic differentiation in kimberlite sills at Benfontein, South Africa. J. Geol. Soc. Lond., 129, 61-85.

Hawthorne, J.B. (1968). Kimberlite sills. Trans. Geol. Soc. S. Afr., LXXI, 291-311.

Hawthorne, J.B. (1975). Model of a kimberlite pipe. Phys. Chem. Earth. 9, 1-15.

Hess, P.C. (1989). Origin of Igneous Rocks. Harvard 


\section{$10^{\text {th }}$ International Kimberlite Conference, Bangalore - 2012}

University Press, Cambridge, 336pp.

MacMahon, B. M. and Haggerty, S.E. (1984). The Benfontein sills: Magmatic reactions and high intrusion temperature. Am. J.Sci., 84, 893-911.

Mitchell, R.H. (1986). Kimberlites: Mineralogy, Geochemistry, and Petrology. Plenum Press, New York, 442pp.

Mitchell, R.H. (1995). Kimberlites, Orangeites and Related rocks. Plenum Press, New York, 410pp.

Schmitz, M.D., Bowring, S.A., de Wit M.J., and Gartz V (2004). Subduction and terrane collision stabilize the western Kaapvaal craton tectosphere 2.9 billion years ago. Earth and Planetary Science, 222, 363376. In the text you are saying "Schmitz 2004" instead oof Schmitz et al. 2004!

Smith, C.B., Gurney, J.J., Skinner, E.M.W. and Ebrahim, N. (1985). Geochemical Character of
South African Kimberlites: A New Approach Based On Isotopic Constraints. Trans. Geol. Soc. S. Afr., 88, 267-280.

Taylor, W.R., Haggerty, S.E. and Tompkins, L.A. (1994). Comparative geochemistry of West African kimberlites: Evidence for a micaceous kimberlite endmember of sublithospheric origin. Geochimica et Cosmochimica Acta., 584017 - 4037

Truswell, J.E. (1970). An Introduction to the Historical Geology of South Africa. Purnell and Sons, Cape Town, 167pp.

Wu, F.Y., Yang, Y.H., Mitchell, R.H., Li, Q.L., Yang, J.H., Zhang, Y.B. (2010). In situ U-Pb age determination and $\mathrm{Nd}$ isotopic analysis of perovskites from kimberlites in Southern Africa and Somerset Island, Canada. Lithos. 115, 205-222 
10 $^{\text {th }}$ International Kimberlite Conference, Bangalore - 2012

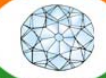

